口 Duygu Özge Demir

HACETTEPE ÜNIVERSITESI

\title{
DYING WORDS
}

\section{ENDANGERED LANGUAGES AND WHAT THEY HAVE TO TELL US}

Evans, N. (2010). Dying Words: Endangered Languages and What They Have To Tell Us. Singapur: Wiley-Blackwell.xxii+287 s.

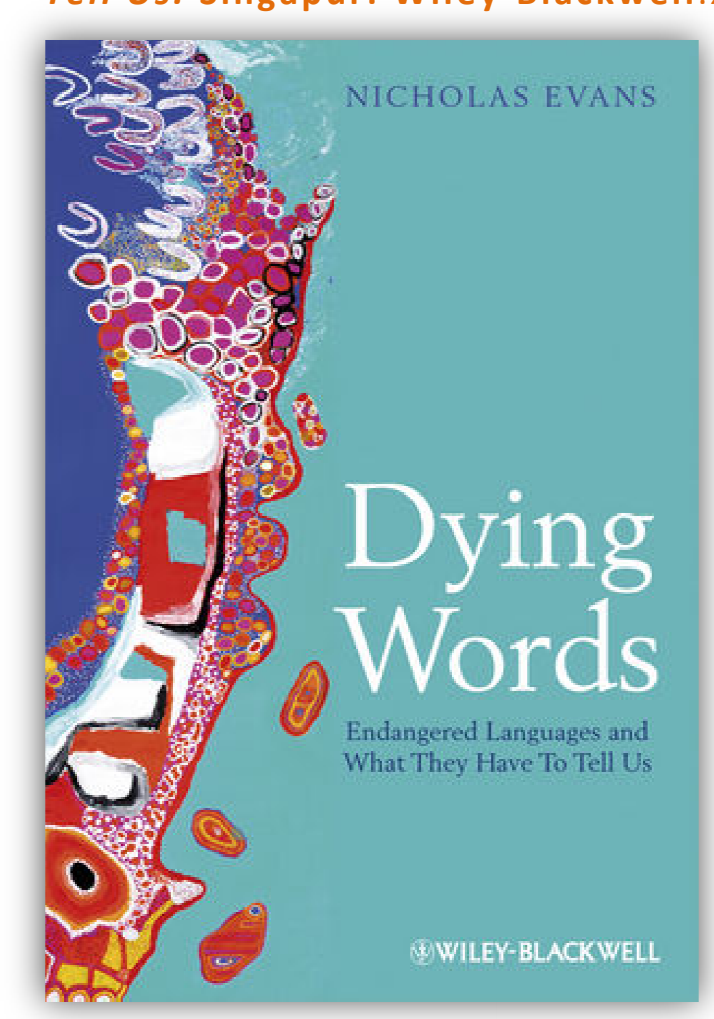

Nicholas Evans tarafından kaleme alınan Dying Words: Endangered Languages and What They Have To Tell Us adlı eser "teşekkür, giriş dilbilimsel malzemenin sunumu üzerine bir not, referanslar, dillerin ve dil ailelerinin indeksi, indeks" ve "sonsöz" dışında "Babil'in Kütüphanesi", "Dillerin Büyük Bir Şöleni", "Eski Bir Kelimeler Atlasındaki Soluk İzler: Diller ve Derin Dünya Tarihi", "Birbirlerini Geliştirmek: Dil, Kültür ve Düşüncenin Beraber Evrimi" ve "Dinleyebildiğimiz Sürece Dinlemek" olmak üzere beş ana bölümden oluşmaktadır. Giriş bölümünde Evans, Avustralya'nın Queensland eyaletinin Bentinck adasında bir Aborjin dili olan Kayardild'den ve bu dilin konuşuru olan Pat Gabori'den ve Avustralya'nın kuzeybatısında Croker adasında konuşulan Ilgar dili ve bu dilin 2003 yılında vefat eden son konuşuru Charlie Wardaga'dan bahsetmektedir.

Evans, bu iki kabile dilinin konuşur sayısı bakımından hiçbir zaman büyük dil olmadıklarını, örneğin Pat Gabori ile tanıştığında Kayardild konuşurlarının sayısının 40'tan daha az olduğunu ve onların da orta yaşlı veya yaşlı kimseler olduğunu ifade etmiştir.

Kayardild dilinin geleceği Bentick adası halkının 1940'ta misyonerler tarafından atalarının topraklarından tehcir edilmesiyle olumsuz etkilenmiş̧ir. Tehcir zamanında bütün halk tekdilliyken, yani Kayardild konuşuruyken o günden sonra yeni doğan hiçbir çocuk bu kabile dilini yeterince öğrenememiştir. Kardeşler arasındaki bağ sayesinde kardeşten kardeşe aktarılan bu dil, tehcirden sonraki ilk yıllarda çocukları günün neredeyse tamamında ebeveynlerinden ayırma ve Aborjin dilini konuşan çocukları cezalandırma uygulamalarıyla kaybolmaya yüz tutmuştur. 
Her dilin farklı bir hikâyeye sahip olduğunu belirten Evans, böyle olağanüstü dillerin suskunlaşıyor olması karşısında duyduğu umutsuzluk nedeniyle bu kitabı kaleme almıştır. Kitap bir insanın ölmesiyle beraber kaybolan her şey ve bunları geri getirmek için neler yapılabileceği hakkındadır.

"Babil'in Kütüphanesi” başlıklı birinci bölüm "Warramurrungunji'nin Çocukları" ve "Kavrayabilmek için 4 Binyı" olmak üzere iki alt başlıktan oluşmaktadır. Babil Efsanesine göre insanlar Tanrı'ya ulaşabilmek için bir kule inşa etmeye çalışma cüretinde bulundukları için cezalandırıldı. Yeryüzünde konuşulan pek çok dil yöneticiler, medya kuruluşları ve sokaktaki insanlar tarafından bir problem gibi görülmekte, hatta bazı ekonomistler tarafından da dil çeşitliliği modern ülkelerde yolsuzluk ve istikrarsızlığın nedenlerinden biri olarak değerlendirilmektedir.

Ortak dilde iletişim sağladığı yararlar nedeniyle birçok yer ve zamanda, örneğin Roma İmparatorluğu'nda Latince, Napolyon Fransası'nda Fransızca ve bugünkü Çin'de Mandarince gibi ölçünler üstü bir ölçünlü dil yaratmak amacıyla, yani büyük şehir ölçünlerini yaymak üzere adeta kampanyalar düzenlenmesine yol açmıştır. Yazar, burada bugün İngilizce, Çince, İspanyolca, Hintçe, Arapça, Portekizce, Fransızca, Rusça gibi kimi dünya dillerinin hızla yayıldığı bir süreç yaşadığımıı ve çok sayıda ulusal dilin de, çoğunluk tarafından konuşuldukları ülkelerde tek bir dil konuşulacak şekilde, konuşur sayısını genişlettiğini vurgulamaktadır. Yazar, aynı zamanda bu dillerin yüksek öğretim ve teknolojik literatür açısından İngilizce ve diğer dünya dillerine karşı zemin kaybettiklerini ileri sürmektedir. Birinci bölümün ilk kısmında şaşırtıcı bir şekilde Babil Kütüphanesi taraflarında cılız da olsa hâlâ var olan dilsel çeşitlilik durumlarını, küçük ölçekli kültürlerde yaygın olup yeryüzünde neden bu kadar çok dil konuşulduğuna pozitif nedenler sunan bazı alternatif oluşum efsanelerini inceleyerek değerlendirmektedir ve daha çok, Jorge Luis Borges tarafından sağlanan katkıyla efsanevi Babil Kütüphanesine bağlı kalmaktadır.

Birinci bölümün ikinci kısmında ise yazar, modern ve tarihi dönemlerdeki insanlar hakkında neler bildiğimiz konusundaki umursamazlığı, yani bu dillerin bize anlatmak istediklerine karşı olan ilgisizliği ve kitabın geri kalanında karşılaşılacak pek çok soruya cevap aranacağını anlatmaktadır.

"Dillerin Büyük Bir Şöleni” adlı ikinci bölüm "Dillerin Galapagos'u” ve "Senin Aklın Benimkinde: Gramerde Sosyal Biliş" olmak üzere iki kısımda incelenmektedir.

Evans, dilbilimsel çalışmalara dair en heyecan verici şeylerden birinin, var olabileceği asla düşünülmemiş diller bularak yerleşmiş önyargıların sınırlarının sürekli olarak zorlanması olduğunu ifade etmektedir. Dilbilime özgü gerçeklerden biri de, şaşırtıcı tipolojik keşiflerden neredeyse hiçbiri, deneysel olarak daha önceki çıkarımlarda öngörülememesinin fiziki bilimlerdekine tamamen zıt bir durum olmasıdır. Çünkü, örneğin matematikçiler, çok sayıda elementin henüz keşfedilmeden önce Mendeleev tarafından ortaya çıkarıldığı Öklit kurallarına dayanmayan geometri ve kimya ile kuramsal boyutta oynamalar yaparak Einstein'ın muhtemel evren teorisini öngörmüşlerdi. Yazar, dilbilimin ise daha çok doğa bilimlerine benzediğinden ve keşfedilen türlerin, düşüncelerimizi biyolojik olarak neyin mümkün olup olmadığına dair gözden geçirmeye sevk ettiğinden söz etmektedir.

İkinci bölümün "Dillerin Galapagos 'u" adlı ilk kısmında yazar," II. Dünya Savaşı sırasında dünyanın en iyi matematikçilerinin, mantıkçılarının ve dilbilimcilerinin hem müttefik hem karşıt taraflarda şifre çözme ve geliştirme uğraşları vb. konulardan çeşitli örnekler vererek dil öğrenenlerin karşılaştığı farklı sorunlardan bahsetmektedir. 
"Senin Aklın Benimkinde: Gramerde Sosyal Biliş" adlı ikinci kısımda ise yazar, seslerin, anlamın ve gramerin her bir parçasını sırasıyla inceleyerek dillerin yapısal çeşitliliğini ele almaktadır. Yazar, bir Çek atasözü olan "Bildiğiniz her farklı dil için, yeni bir insansınız" cümlesini örnek göstermek suretiyle, dillerin kelimeler ve deyimler bakımından nasıl bir çeşitlilik gösterdiğini ayrıntılarıyla açıklamaktadır.

"Eski Bir Kelimeler Atlasındaki Zayıf İzler: Diller ve Derin Dünya Tarihi" adlı üçüncü bölümde yazar, I. Dünya Savaşı'nın katliamları esnasında, Çekoslovakyalı genç profesör Bedrich Hrosny'nin Avusturya-Macaristan Ordusu'nda görevlendirildiğini ve bu esnada onun Türkiye'de Boğazköy yakınlarındaki kil tabletlerdeki Hitit çivi yazılarını inceleme imkanı bulduğundan söz etmektedir. Evans, bazı tabletlerde ise, Akat dili için kullanılmış çivi yazıları olmasına rağmen, bu yazıların farklı ve bilinmeyen bir dile de işaret ettiklerini belirterek 1915 yılında Hrosny'nin bu tabletlere yazılmış dillle ilgili yapmış olduğu şifrelemeler sayesinde, bu dilin Hitit İmparatorluğu’nun dili olduğunun anlaşıldığını ifade etmektedir.

Üçüncü bölüm, "Ortak Kaynaktan Doğma", "Kelimelerin Evreni İçinde Seyahatler: Eski kelimeleri Eski Dünyayla Birleştirmek" ve Şifreleme için Anahtarlar: Yaşayan Diller, Unutulmuş El Yazılarını Nasıl Çözebilir adlı üç kısımda incelenmektedir.

"Ortak Kaynaktan Doğma” adlı ilk kısma Evans, bir dili konuşanların, kendi dilleriyle diğerlerini karşılaştırdıkları zaman, birtakım benzerlikler tespit ettiklerinden bahsederek başlamaktadır ve kendisinin ilk dilbilim profesörü Bob Dixon'in bebekler tarafından kullanılan sınılı sesler sebebiyle (ör.'anne' için 'mama', 'baba' için 'papa') kelimelerin birbirine benzeyebileceğini, bu durumun abartılmaması gerektiğini ileri sürmesi gibi konulardan da örnekler vermektedir. Ayrıca yazar, benzerliklerin, dilbilimcilerin "ödünç alma" diye adlandırdıkları durumdan, yani kelimelerin bir dilden öteki dile geçmesinden de kaynaklanabileceğini ortaya koymaktadır.

"Kelimelerin Evreni İçinde Seyahatler: Eski Kelimeleri Eski Dünyayla Birleştirmek" adlı ikinci kısımda yazar, tarihsel dilbilimin eski kelimeleri anlamamızdaki katkısını kavramanın yolunun dilbilimsel kanıtlar ile arkeoloji, genetik ve karşılaştırmalı etnografya gibi diğer bilimlerin temas noktalarının bulunarak rekonstrüksüyonu yapılmış kelime-dünyalarını (word-worlds) belirli zamanlara, yerlere, arkeolojik kültürlere ve kişilere ilişkilendirmekten geçtiğinden bahsetmektedir.

"Şifreleme İçin Anahtarlar: Yaşayan Diller, Unutulmuş El Yazılarını Nasıl Çözebilir" adlı üçüncü kısımda ise yazar, "bilinmeyen eski dillerle ilgili asıl sorunun, ister eski ister yeni olsun birbiriyle ilişkili diller bulmak olduğunu belirtmekte ve "Eğer bilinmeyen bir dilin, bilinen bir dil ile ilişkisi saptanamıyorsa ve ayrıntılı iki dilli bir metin yoksa, çeviri imkansızdır." şeklinde bir alıntıyla söze başlamaktadır. Paralel metinler mevcutsa, dilin dayanak noktasının genellikle özel adlar olduğunu belirten yazar, ayrıca, hedef kültür hakkında genel bir bilgi elde edilmesinin de gerekliliğinden bahsetmekte, ayrıca hedef kültüre dair bilgi sahibi olmanın faydasına da değinmektedir.

"Birbirlerini Geliştirmek: Dil, Kültür ve Düşüncenin Beraber Evrimi” adlı dördüncü bölümde yazar dil çeşitliliğinin insan, kültür ve düşünce ile olan bağını ele almaktadır. İnsan ırkının evrimini dansa benzeten yazar, bu dansın partnerlerini "fiziksel evrim" (genlerimiz) ile "kültürel ve dilsel evrim" olarak tanımlamaktadır. Yazar bu bölümde sadece kültür ve genlerin evrimini değil, aynı zamanda dil ve düşünce biçimleri ile sıradan dil ve dilin şiirsel kullanımı arasındaki ilişkiyi de incelemektedir. 
“Aklın Çitleri: Dil Düşünceyi Nasıl Eğitir?” adlı birinci kısma yazar, farklı dillerin zihnimizde farklı düşünce motiflerini tetiklediğini ve bir dili anlamak için zihnimizde doğru yapıların oluşması gerektiğini belirterek başlamaktadır. Bu girişten sonra dilin düşünce üzerindeki etkisini "Farklı dilleri konuşanlar gerçekten farklı düşünürler mi?" ve "íki dili beraber kullananlar konuştukları dilleri değiştirirken düşünce yapılarını da değiştirdikleri dillere uydururlar mı?" gibi sorularla konuyu derinlemesine irdeleyerek "dilsel görecelik" ilkesine göre cevaplar aramaktadır. Bu ilkeye göre farklı gramerleri kullananlar, aynı gözlemleri farklı şekilde tasvir edip yorumlayabilmektedirler.

Dördüncü bölümün ikinci kısmında ise Evans, dilin değişik kullanımlarından biri olan şiirsel kullanımı incelemektedir. Her dilin kendi özel stillerini oluşturduğunu belirten yazar bunları dil oyunları, bulmacalar, şiirsel, şarkısal, törensel şekiller olarak örneklemektedir. Bu bölümde ayrıca az konuşurlu dilleri ilgilendiren "Atalardan kalan bir dil artık konuşulmazsa, kültür de yok olur mu?" sorusu üzerinde durulmaktadır.

"Dinleyebildiğimiz Sürece Dinlemek" adlı son bölümde dilleri insan zihninin dışında koruma yollarından ve bunların işleyişleri ile evrimlerinden bahsedilmektedir. Gelişen teknoloji ile "küçük diller" dünyanın bir köşesinden diğer bir köşesine cebe sığabilen kayıt cihazları ve diskler tarafından taşınabildiğini, internet imkânları kullanılarak video ve sohbet ortamları aracılığıyla bu dilleri konuşan genç nesillere yeni vizyonlar sunulduğunu belirten Evans, bu gelişmelerin dilbilimcilerin kaydedebildiği dillerin sayı ve niteliğini arttırdığına değinmektedir. Yazar ayrıca dilin kaybolmayacak bir şekilde nasıl belgeleneceği konusunda örnekler vererek teknolojik imkânların sınırlarını tartışmaktadır.

Son bölümün tek alt başlığı olan "Dünyayı Yenilemek" adlı kısımda yazar, dillerin kaybolma tehlikesinin büyüklüğünün altını çizerek toplulukların atalarına ait dillerini kaybetmek zorunda kaldıklarını ve bu kaybın hangi aşamalardan geçerek gerçekleştiğini anlatmaktadır. Son olarak bütün bu teknolojilerin ve modern dilbilimciliğin birleştirilmiş imkânlarının hâlâ duyulabiliyorken bu değerli dil miraslarına, nasıl katkıda bulunabileceği sorusuna yanıt arayarak kitabı sonlandırmaktadır. 